\title{
molecules
}

ISSN 1420-3049

www.mdpi.com/journal/molecules

Article

\section{Caffeic Acid Derivatives from Eupatorium perfoliatum L.}

\section{Mareike Maas, Frank Petereit and Andreas Hensel *}

University of Münster, Institute for Pharmaceutical Biology and Phytochemistry (IPBP), Hittorfstraße 56, D-48149 Münster, Germany

* Author to whom correspondence should be addressed; E-Mail: ahensel@uni-muenster.de; Tel.: +49 251833 3380; Fax: +492518338341.

Received: 25 November 2008; in revised form: 16 December 2008 / Accepted: 18 December 2008 / Published: 23 December 2008

\begin{abstract}
From the ethyl acetate soluble fraction of a methanol/water extract of the herb Eupatorium perfoliatum L. (Asteraceae) six caffeic acid derivatives have been isolated and identified by 1D- and 2D-NMR spectroscopic data. Besides the common quinic acid derivatives 5-caffeoylquinic acid (chlorogenic acid), 3-caffeoylquinic acid (neochlorogenic acid) and 3,5-dicaffeoylquinic acid, three up to now unknown depsides of caffeic acid with glucaric acid have been isolated: 2,5-dicaffeoylglucaric acid, 3,4-dicaffeoylglucaric acid, and 2,4- or 3,5-dicaffeoylglucaric acid.
\end{abstract}

Keywords: Eupatorium perfoliatum L.; Asteraceae; Flavonoids; Dicaffeoylglucaric acid; NMR.

\section{Introduction}

Eupatorium perfoliatum L., Asteraceae, is a medicinal herb from the Northern American continent known as boneset or thoroughwort. It has been extensively used by the native inhabitants, especially for the treatment of fever and flu. European settlers adopted the use of the herb which led to a monograph in the USP and NF in the $19^{\text {th }}$ and beginning of $20^{\text {th }}$ century [1-4]. Today E. perfoliatum is mainly used in central Europe as an immunostimulating remedy.

E. perfoliatum is phytochemically characterized by the occurrence of flavonoids [5-7], sesquiterpene lactones [8-10], triterpenes and steroids [11, 12], and by small amounts of volatile oil [13]. An alkaline-soluble polysaccharide fraction was shown to exhibit immunostimulating activities under in vitro conditions [14-16]. Furthermore, investigations concerning antiinflammatory [17, 18], 
cytotoxic and antibacterial [19] as well as antiprotozoal [20] activities have been carried out. The few clinical studies dealing with different preparations of E. perfoliatum only partly support the phytotherapeutic indications [21-23]. For a review on E. perfoliatum see also Maas and Hensel [24].

This study deals with the characterisation and isolation of phenolic compounds in the herb of $E$. perfoliatum with a focus on hydroxycinnamic acid derivatives. These substances have not been investigated in this plant so far. The study led to the description of three up to now unknown caffeoylglucaric acid derivatives, besides some commonly occurring caffeoylquinic acids, e. g. chlorogenic acid.

\section{Results and Discussion}

A crude methanol/water $(70 / 30 \mathrm{~V} / \mathrm{V})$ extract from the dried aerial parts of E. perfoliatum was partitioned between ethyl acetate and acidic aqueous solution to enrich the hydroxycinnamic acid derivatives as well as the flavonoid glycosides in the ethyl acetate fraction. The ethyl acetate fraction was analysed by HPLC, resulting in typical chromatograms as presented in Figure 1.

Figure 1: RP-HPLC chromatogram of the ethyl acetate fraction obtained from a partition of a $\mathrm{MeOH} /$ water extract from E. perfoliatum; detection wavelength $325 \mathrm{~nm}$. Peaks $\mathbf{C 1}$ to C8 correspond to caffeic acid derivatives, peaks F1 to F4 correspond to flavonoids.

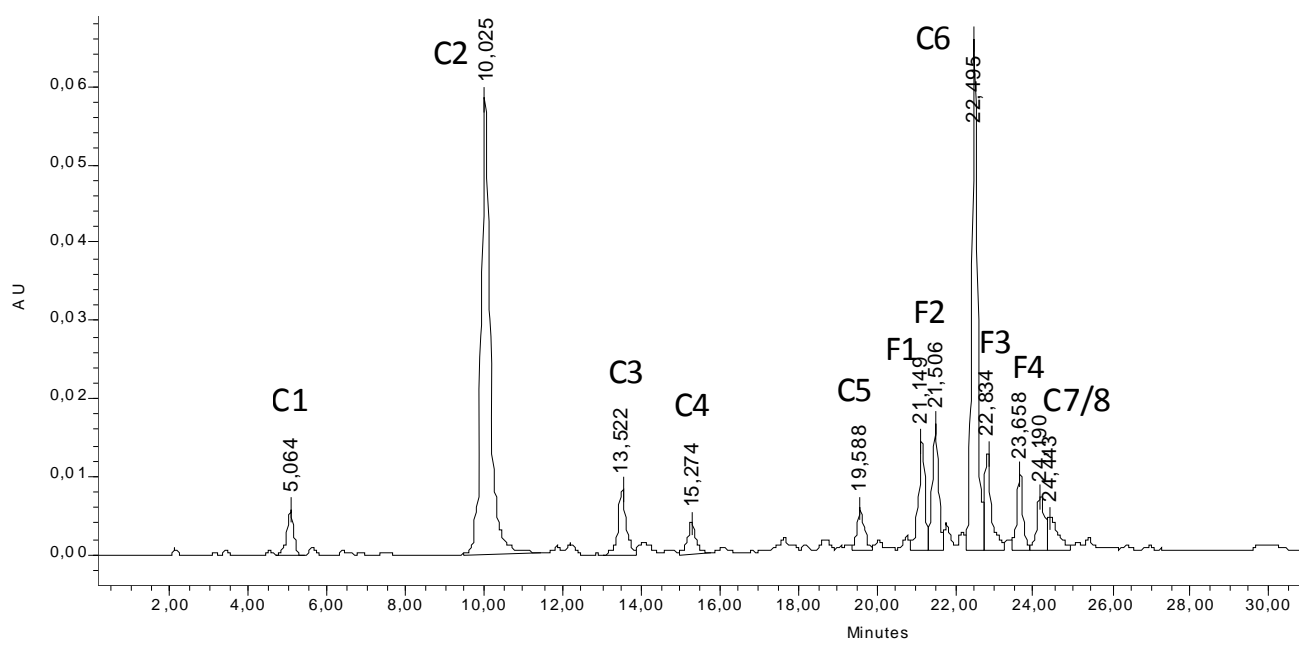

By analysing the recorded DAD-UV spectra, eight of the twelve numbered peaks were assigned to hydroxycinnamic derivatives (C1 to C8, $\lambda_{\max }$ at approx. $325 \mathrm{~nm}$ ) and four to flavonoids (F1 to F4, $\lambda_{\max }$ at approx. $354 \mathrm{~nm}$ ). The four flavonoid glycosides were identified by comparison of retention times and spiking experiments with the respective reference standards as hyperoside (quercetin-3-O- $\beta$ galactoside, F1), isoquercitrin (quercetin-3-O- $\beta$-glucoside, F2), trifolin (kaempferol-3-O- $\beta$ galactoside, F3) and astragalin (kaempferol-3-O- $\beta$-glucoside, F4). The assignment was confirmed by TLC.

Isoquercitrin and trifolin have not been reported as constituents of E. perfoliatum up to now, whereas astragalin and hyperoside, as well as the aglyca kaempferol and quercetin have been described by Wagner et al. [6] and Habtemariam [5]. 
To clarify the structural features of the caffeic acid compounds the ethyl acetate extract was subsequently fractionated on a preparative scale on Sephadex ${ }^{\circledR}$ LH-20, followed by different purification steps using fast centrifugal partition chromatography (FCPC), medium pressure liquid chromatography (MPLC) and preparative HPLC (see Experimental section). The five hydroxycinnamic acid derivatives $\mathbf{C} \mathbf{1}$ to $\mathbf{C 5}$ were isolated as pure compounds and identified by the respective ${ }^{1} \mathrm{H}$ - and ${ }^{13} \mathrm{C}$-NMR spectra, combined with ${ }^{1} \mathrm{H}-{ }^{1} \mathrm{H}$-correlated spectroscopy (COSY), heteronuclear single quantum coherence spectroscopy (HSQC) and heteronuclear multiple bond correlation spectroscopy (HMBC).

The two main constituents of the ethyl acetate fraction, C2 and C6, were identified as 5-O-caffeoylquinic acid (chlorogenic acid) and 3,5-O-dicaffeoylquinic acid by ${ }^{1} \mathrm{H}-\mathrm{NMR}$ spectroscopy (data not shown) and comparison with recorded data $[25,26]$. Peak $\mathbf{C 1}$ proved to be a structural analogue of chlorogenic acid, which by comparison with known spectra was identified as 3-O-caffeoylquinic acid (neochlorogenic acid) [25].

The minor peaks C7 and C8 eluted in the same Sephadex ${ }^{\circledR}$ LH-20 fraction as C6. The UV spectra were typical for hydroxycinnamic acid derivatives, and because of the similar chromatographic behaviour of these three substances, C7 and C8 were also tentatively identified as dicaffeoylquinic acid derivatives. Because of the limited amounts a detailed NMR study was not possible.

The ${ }^{1} \mathrm{H}-\mathrm{NMR}$ spectra of C3, C4 and C5 all showed the typical signal sets (aromatic AMX spin system, olefinic side chain) of two caffeic acids in the region between 6 and 8 ppm, indicating the presence of two inequivalent caffeoyl moieties in each compound. In the region between 4 and $6 \mathrm{ppm}$ four signals appeared, two $d$ and two $d d$, of which in each case two were shifted downfield, indicating the site of esterification with caffeic acid. In $\mathbf{C 3}$ one $d$ and one $d d$, in $\mathbf{C 4}$ the two $d d$, and in $\mathbf{C 5}$ and the two $d$ were shifted downfield. Further NMR studies including ${ }^{13} \mathrm{C}, \mathrm{H}-\mathrm{H}-\mathrm{COSY}$, HSQC and HMBC indicated the presence of a hexaric acid as alcoholic moiety, esterified with two caffeoyl rests each.

Hexaric acid itself has six diastereomers of which four are symmetric (allaric, mannaric, idaric and galactaric acid) and two asymmetric (altraric and glucaric acid). C3 showed a asymmetric esterification pattern (positions 2,4 or 3,5), so the caffeic acid signals could be duplicated with any of the possible hexaric acids. To determine the existing diastereomer, compound C3 was hydrolysed under alkaline conditions [27]. Shortly afterwards a ${ }^{1} \mathrm{H}-\mathrm{NMR}$ spectrum of the reaction mixture was recorded and the signals related to the hexaric acid were compared with published spectra [27]. The hydrolysed hexaric acid showed four inequivalent signals, indicating the existence of an asymmetric acid, which was further identified as glucaric acid. From the NMR data it cannot be distinguished whether C3 is the 2,4- or the 3,5-dicaffeoylglucaric acid. As the rotational conformation of the molecule is not fixed, it is not possible to obtain information about the dihedral angles by the coupling constants. For the same reason circular dichroism experiments will not be successful. Perhaps x-ray structure analysis will help to determine the absolute stereochemistry. Up to this point $\mathbf{C} 3$ can only be referred to as 2,4- or 3,5-dicaffeoylglucaric acid.

For compounds C4 and C5, with a symmetric substitution pattern (positions 3,4 and 2,5, resp.), a symmetric hexaric acid had led to two equivalent caffeic acid moieties with only one set of signals. As the caffeic acid signals were doubled in both cases, only altraric or glucaric acid are possible as the hexaric acid component. For analogy reasons, these two compounds were identified as 3,4- 
dicaffeoylglucaric acid (C4) and 2,5-dicaffeoylglucaric acid (C5). The structures of compounds C3, C4 and C5 are shown in Figure 2.

Figure 2. Structure of dicaffeoylglucaric acid derivatives C3, C4 and C5 from E. perfoliatum.

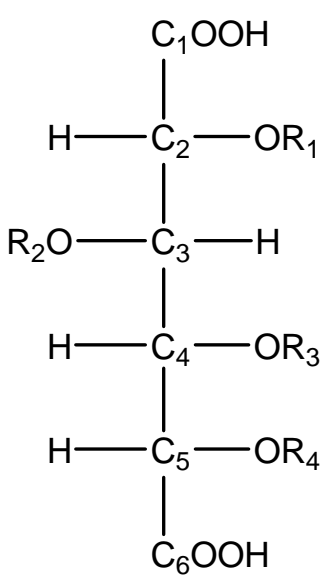<smiles></smiles>

C3: $\mathrm{R}_{1}=\mathrm{R}_{3}=$ caffeoyl, $\mathrm{R}_{2}=\mathrm{R}_{4}=\mathrm{H}$ or $\mathrm{R}_{2}=\mathrm{R}_{4}=$ caffeoyl, $\mathrm{R}_{1}=\mathrm{R}_{3}=\mathrm{H}$

C4: $\mathrm{R}_{2}=\mathrm{R}_{3}=$ caffeoyl, $\mathrm{R}_{1}=\mathrm{R}_{4}=\mathrm{H}$

C5: $\mathrm{R}_{1}=\mathrm{R}_{4}=$ caffeoyl, $\mathrm{R}_{2}=\mathrm{R}_{3}=\mathrm{H}$

Depsides of caffeic acid and quinic acid are widespread throughout all kind of plants. Remarkably high concentrations of chlorogenic acid and caffeic acid can be found in the green seeds of Coffea arabica and canephora. Many members of the family Asteraceae are also known to contain caffeoylquinic acid derivatives, e. g. mountain arnica (Arnica montana) or artichoke (Cynara scolymus). This group of compounds exhibit antioxidative and antiinflammatory properties; the dicaffeoylquinic acids in artichoke leaves are part of the active ingredients responsible for the choleretic effect [28]. Caffeoylquinic acids are known compounds in other Eupatorium species [2931], but have not been described for Eupatorium perfoliatum before.

In contrast to these common compounds depsides of hydroxycinnamic acids with hexaric acids are very rarely described. The first description of monocaffeoylglucaric acid was published for tomato leaves (Lycopersicon esculentum) [32], followed by a report for the same derivative from Cestrum euanthes, both from the Solanaceae family [33]. Depsides of coumaric and ferulic acid with glucaric and galactaric acid were found both in Secale cereale, Poaceae [34] and Citrus species, Rutaceae [35, 36]. Two reports describe the occurrence of hydroxycinnamoylhexaric acid derivatives in the Asteraceae family: in yacon root (Smallanthus sonchifolius) 2,4- or 3,5-dicaffeoyl-, 2,5-dicaffeoyl- and 2,3,5- or 2,4,5-tricaffeoylaltraric acid have been found [27], and 2-[(3S)-3-hydroxybutanoat]-3,4,5tricaffeoylglucaric acid and 3,4,5-tricaffeoylglucaric acid (Leontopodic acid and Leontopodic acid B) have been isolated in edelweiss (Leontopodium alpinum) [37, 38]. Concerning the two Leontopodic acids it is not clear why the authors excluded the 2,3,4-tricaffeoylglucaric acid derivatives as possible conformational isomers.

Strack et al. [39] discovered the biochemical relationship of chlorogenic acid and caffeoylglucaric acid in tomato cotyledons: caffeic acid is transmitted from chlorogenic acid to glucaric acid by a specific enzyme. So it can be assumed that the occurrence of chlorogenic acid is a precondition for the 
development of caffeoylhexaric acid derivatives, but a special enzymatic pathway is needed to perform the transformation. These enzymes obviously seem to be very uncommon.

The hexaric acid derivatives of edelweiss and yacon have been shown to exhibit antioxidative and radical scavenging activities [37, 40] and the caffeoylglucaric acid from tomato possesses inhibiting activity against the tomato fruit worm [32]. Beside these data, nothing is known about possible pharmacological properties of this group of substances.

The three dicaffeoylglucaric acid derivatives identified in the present study (3,4-dicaffeoylglucaric acid, 2,5-dicaffeoylglucaric acid and 2,4- or 3,5 dicaffeoylglucaric acid) have not been reported before. Therefore they are promising substances for a further research on the activity determining constituents of E. perfoliatum.

Because of their rare occurrence, these glucaric acid derivatives can be useful for identity control of herbal material of E. perfoliatum. In the respective official monograph of the homeopathic pharmacopoeia [41] no unambiguous chromatographic data for quality control, especially for identification, are published. After validation, the analytical HPLC method described in this report and based on the identification of four flavonoids and several hydroxycinnamic acid derivatives may be a useful tool, not only for identity but also for stability control because these compounds tend to exhibit fast degradation by oxidative processes when stored under humid and oxidative conditions.

\section{Experimental}

\section{General}

NMR spectra were recorded on a Varian AS 400 Mercuryplus spectrometer. Mass spectra were obtained on a Finnigan MAT mass spectrometer with electrospray ionisation. Optical rotations were measured with a Perkin-Elmer 341 digital polarimeter in methanol. Analytical HPLC was performed on a ProSep C18-5 $\mu \mathrm{m}$ column (Latek, Eppelheim, Germany), with a ternary gradient containing acetonitrile, methanol and $0.1 \%$ trifluoroacetic acid in aqueous solution [26]. The Waters 996 photodiode array detector was set at $325 \mathrm{~nm}$ ( $\lambda_{\max }$ of caffeic acid derivatives). TLC Silica gel $60 \mathrm{~F}_{254}$ on Aluminium sheets (Merck, Darmstadt, Germany) was used for analytical TLC with ethyl acetate/water/formic acid (90:5:5) as mobile phase. Hydroxycinnamic acid derivatives were detected by a blue fluorescence at $366 \mathrm{~nm}$ and a greenish-blue fluorescence at $366 \mathrm{~nm}$ after spraying with diphenylboryloxyethylamine in methanol ("Naturstoffreagenz A“). Flavonoid glycosides were detected as light orange spots at $366 \mathrm{~nm}$ after spraying with the reagent. Reference substances were taken from the reference library of the Institute for Pharmaceutical Biology and Phytochemistry, Münster. The hydrolysis of 2,4-/3,5-dicaffeoylglucaric acid was performed according to Takenaka et al. [27].

\section{Plant material}

Dried Eupatorium perfoliatum herb (Lot 3458) was purchased from Alfred Galke, Gittelde, Germany. A voucher specimen has been deposited in the documentation file of the Institute of Pharmaceutical Biology and Phytochemistry (EP-1). The material was grown in summer 2005 in northern parts of the United States of America (U.S.A.) under continental climate conditions. The 
material was delivered in January 2006 to Germany and was obtained as bulk material from the supplier. The material was investigated according the specifications of the official Homeopathic Pharmacopoeia HAB 2000, Germany. All results obtained fulfilled the respective specifications of the official Pharmacopoeia, therefore batch 3458 is deemed to be a representative lot.

\section{Extraction and isolation}

The dried and cut plant material $(1 \mathrm{~kg})$ was extracted with cold methanol/water $(70 / 30 \mathrm{~V} / \mathrm{V}$, approx. $20 \mathrm{~L}$ ) by rotor-stator extraction (Ultra-Turrax ${ }^{\circledR}$ ). The combined extracts were concentrated to about $1 \mathrm{~L}$ of aqueous solution, and filtered to remove the precipitated chlorophyll. Partition between aqueous solution and dichloromethane was used to further remove lipophilic substances. The aqueous solution was acidified to $\mathrm{pH} 2$ with $1 \mathrm{~N} \mathrm{HCl}$ and partitioned with ethyl acetate. After removal of the solvents, the residues were lyophilized to yield $76 \mathrm{~g} \mathrm{H}_{2} \mathrm{O}$-soluble fraction (W) and $16 \mathrm{~g}$ EtOAc-soluble fraction (E). E was further fractionated by column chromatography with Sephadex ${ }^{\circledR}$ LH-20 (730 x 55 mm inner diameter) using methanol/water 50/50 (13 L), followed by acetone/water 7/3 (2.5 L) to yield 20 fractions. Fractions were monitored by TLC and characterised by analytical HPLC.

Fraction $9(1,270 \mathrm{mg})$ was analysed directly, leading to the identification of chlorogenic acid (5caffeoylquinic acid, C2). Fractions $7(320 \mathrm{mg}), 12(160 \mathrm{mg})$ and $20(1,300 \mathrm{mg})$ were fractionated by fast centrifugal partition chromatography (FCPC), performed on a CPC Kromaton (Angers, France) with a $200 \mathrm{~mL}$ rotor. For fractions 7 and 12 a solvent system consisting of ethyl acetate/acetone/diluted $\mathrm{HCl}(\mathrm{pH} \mathrm{2}) 1 / 1 / 1(\mathrm{~V} / \mathrm{V} / \mathrm{V})$ was used, for separation of fraction 20 the solvent system was nheptane/ethyl acetate/methanol/acetic acid $1 \%$ 1/2/1/2 (V/V/V/V). In all cases the upper phase served as mobile phase (ascending mode). 3-caffeoylquinic acid (C1, $50 \mathrm{mg}$ ) was isolated from fraction 7 , while fraction 20 yielded 3,5-dicaffeoylquinic acid (C6, $208 \mathrm{mg}$ ). 2,4- or 3,5-dicaffeoylglucaric acid (C3, $46 \mathrm{mg}$ ) was purified out of a subfraction of fraction 12 by preparative HPLC (Hypersil ODS 5 $\mu \mathrm{m}, 250 \mathrm{~mm} \times 16 \mathrm{~mm}$ inner diameter, gradient with acetonitrile and $1 \%$ trifluoroacetic acid in aqueous solution, UV detector set at $325 \mathrm{~nm}$, flow $5 \mathrm{ml} / \mathrm{min}$ ).

Fractions $15(640 \mathrm{mg})$ and $16(820 \mathrm{mg})$ were separated by MPLC (Spot Liquid Chromatography Flash from Armen Instrument, France) with a methanol/water gradient on a RP-18 phase (SVF D26 RP 18, 40-63 $\mu \mathrm{m}, 37 \mathrm{~g}$, Merck Chimie SAS). 3,4-Dicaffeoylglucaric acid (C4, $10 \mathrm{mg}$ ) was obtained from fraction 15, while fraction 16 contained 2,5-dicaffeoylglucaric acid (C5, $33 \mathrm{mg})$.

\section{2,4-/3,5-Dicaffeoylglucaric acid (C3)}

$[\alpha]^{20}{ }_{D}=-54.56^{\circ}\left(c=0.0011 \mathrm{~g} \cdot \mathrm{mL}^{-1}\right.$ in $\left.\mathrm{MeOH}\right)$; ESI-MS: [M - H] ${ }^{-} \mathrm{m} / \mathrm{z}$ 533; NMR (atom numbers with ' or " refer to the caffeoyl moieties): ${ }^{1} \mathrm{H}-\mathrm{NMR}$ (methanol- $\mathrm{D}_{3}, 400 \mathrm{MHz}, \mathrm{CD}_{3} \mathrm{OH}=3.31 \mathrm{ppm}$,): $\delta$ $4.42(d, \mathrm{~J}=1.9 \mathrm{~Hz}, \mathrm{H}-2$ or H-5), $\delta 4.71$ (dd, $\mathrm{J}=2.4$ and $3.4 \mathrm{~Hz}, \mathrm{H}-3$ or H-4), $\delta 5.34$ (d, J = 1.6 Hz, H-2 or $\mathrm{H}-5$, esterified with caffeic acid), $\delta 5.46(d d, \mathrm{~J}=4.4$ and $6.4 \mathrm{~Hz}, \mathrm{H}-3$ or $\mathrm{H}-4$, esterified with caffeic acid), $\delta 6.26 / 6.29\left(d, \mathrm{~J}=16.0 \mathrm{~Hz}, \mathrm{H}-8^{\prime}\right.$ and $\left.\mathrm{H}-8^{\prime \prime}\right), \delta 6.67 / 6.74\left(d, \mathrm{~J}=8.2, \mathrm{H}-5^{\prime}\right.$ and $\left.\mathrm{H}-5^{\prime \prime}\right), \delta 6.83 / 6.88$ $\left(d d, \mathrm{~J}=2.0\right.$ and 8.2, H-6' and H-6' $\left.{ }^{\prime \prime}\right), \delta 6.97 / 6.97\left(d, \mathrm{~J}=1.9 \mathrm{~Hz}, \mathrm{H}-2^{\prime}\right.$ and $\left.\mathrm{H}-2^{\prime \prime}\right), \delta$ 7.50/7.60 $(d, \mathrm{~J}=$ $15.9 \mathrm{~Hz}, \mathrm{H}-7^{\prime}$ and $\left.\mathrm{H}-7^{\prime \prime}\right)$; ${ }^{13} \mathrm{C}-\mathrm{NMR}\left(\mathrm{CD}_{3} \mathrm{OD}, 100 \mathrm{MHz}, \mathrm{CD}_{3} \mathrm{OD}=49,15 \mathrm{ppm}\right): \delta 70.19$ (C-3 or C-4), $\delta 71.21$ (C-2 or C-5), $\delta 75.67$ (C-2 or C-5, esterified with caffeic acid), $\delta 75.89$ (C-3 or C-4, esterified with caffeic acid), $\delta 114.53 / 115.17$ (C-8' and C-8' $), \delta 115.38 / 115.66$ (C-2' and C-2' '), $\delta 116.51$ (C-5' 
and $\left.\mathrm{C}-5^{\prime \prime}\right), \delta$ 123.16/123.32 (C-6' and C-6"'), $\delta$ 127.80/127.82 (C-1' and C-1' '), $\delta$ 146.81/146.90 (C-3' and $\left.\mathrm{C}-3^{\prime \prime}\right), \delta 148.00 / 148.16\left(\mathrm{C}-7^{\prime}\right.$ and $\left.\mathrm{C}-7^{\prime \prime}\right), \delta 149.59$ (C-4' and C-4' $), \delta 168.45 / 168.58\left(\mathrm{C}-9^{\prime}\right.$ and C$\left.9^{\prime \prime}\right), \delta 171.62$ (C-1 or C-6), $\delta 175.11(\mathrm{C}-1$ or C-6).

\section{3,4-Dicaffeoylglucaric acid (C4)}

$[\alpha]^{20}{ }_{D}=-161.47^{\circ}\left(c=0.0010 \mathrm{~g} \cdot \mathrm{mL}^{-1}\right.$ in $\left.\mathrm{MeOH}\right)$; ESI-MS: [M - H] $]^{-} \mathrm{m} / \mathrm{z}$ 533; NMR (atom numbers with ' or " refer to the caffeoyl moieties): ${ }^{1} \mathrm{H}-\mathrm{NMR}$ (methanol- $\left.\mathrm{D}_{3}, 400 \mathrm{MHz}, \mathrm{CD}_{3} \mathrm{OH}=3.31 \mathrm{ppm}\right): \delta$ $4.53(d, \mathrm{~J}=2.2 \mathrm{~Hz}, \mathrm{H}-2$ or H-5), $\delta 4.64(d, \mathrm{~J}=1.6 \mathrm{~Hz}, \mathrm{H}-2$ or H-5), $\delta 5.79$ (dd, $\mathrm{J}=2.4$ and $8.0 \mathrm{~Hz}, \mathrm{H}-3$ or H-4), $\delta 5.99$ (dd, $\mathrm{J}=2.0$ and $8.0 \mathrm{~Hz}, \mathrm{H}-3$ or H-4), $\delta 6.16 / 6.18\left(d, \mathrm{~J}=15.8 \mathrm{~Hz}, \mathrm{H}-8^{\prime}\right.$ and H-8 $\left.{ }^{\prime \prime}\right), \delta$ $6.73 / 6.76\left(d, \mathrm{~J}=2.6 \mathrm{~Hz}, \mathrm{H}-5^{\prime}\right.$ and $\left.\mathrm{H}-5^{\prime \prime}\right), \delta 6.85 / 6.88\left(d d, \mathrm{~J}=2.0\right.$ and $4.0 \mathrm{~Hz}, \mathrm{H}-6^{\prime}$ and $\left.\mathrm{H}-6^{\prime \prime}\right), \delta$ $6.97 / 7.00\left(d, \mathrm{~J}=1.6 \mathrm{~Hz}, \mathrm{H}-2^{\prime}\right.$ and $\left.\mathrm{H}-2^{\prime \prime}\right), \delta 7.48 / 7.52\left(d, \mathrm{~J}=15.8 \mathrm{~Hz}, \mathrm{H}-7^{\prime}\right.$ and $\left.\mathrm{H}-7^{\prime \prime}\right) ;{ }^{13} \mathrm{C}-\mathrm{NMR}$ $\left(\mathrm{CD}_{3} \mathrm{OD}, 100 \mathrm{MHz}, \mathrm{CD}_{3} \mathrm{OD}=49.15 \mathrm{ppm}\right): \delta 71.39$ (C-2 or C-5), $\delta 71.84$ (C-2 or C-5), $\delta 74.33(\mathrm{C}-3$ or $\mathrm{C}-4), \delta 75.45$ (C-3 or C-4), $\delta 114.76 / 114.98$ (C-8' and C-8' $), \delta 115.19 / 115.32$ (C-2' and C-2' $), \delta$ $116.42\left(\mathrm{C}-5^{\prime}\right.$ and $\left.\mathrm{C}-5^{\prime \prime}\right) \delta 123.25 / 123.35\left(\mathrm{C}-6^{\prime}\right.$ and $\left.\mathrm{C}-6^{\prime \prime}\right), \delta 128.14\left(\mathrm{C}-1^{\prime}\right.$ and $\left.\mathrm{C}-1^{\prime \prime}\right), \delta 146.97$ (C-3' and $\left.\mathrm{C}-3^{\prime \prime}\right), \delta$ 147.86/148.01 (C-7' and C-7' '), $\delta 149.66$ (C-4' and C-4' '), 168.23/168.67 (C-9' and C9"), 174.69 (C-1 and C-6).

\section{2,5-Dicaffeoylglucaric acid (C5)}

$[\alpha]^{20}{ }_{D}=-39.36^{\circ}\left(c=0.0010 \mathrm{~g} \cdot \mathrm{mL}^{-1}\right.$ in $\left.\mathrm{MeOH}\right)$; ESI-MS: $[\mathrm{M}-\mathrm{H}]^{-} \mathrm{m} / \mathrm{z}$ 533; NMR (atom numbers with ' or " refer to the caffeoyl moieties): ${ }^{1} \mathrm{H}-\mathrm{NMR}$ (methanol- $\mathrm{D}_{3}, 400 \mathrm{MHz}, \mathrm{CD}_{3} \mathrm{OH}=3.31 \mathrm{ppm}$ ): $\delta$ $4.22(d d, \mathrm{~J}=5.2$ and $5.2 \mathrm{~Hz}, \mathrm{H}-3$ or H-4), $\delta 4.25$ (dd, $\mathrm{J}=4.6$ and $4.6 \mathrm{~Hz}, \mathrm{H}-3$ or H-4), $\delta 5.14(d, \mathrm{~J}=5.7$ $\mathrm{Hz}, \mathrm{H}-2$ or H-5), $\delta 5.32$ ( $d, \mathrm{~J}=4.2 \mathrm{~Hz}, \mathrm{H}-2$ or H-5), $\delta 6.33 / 6.35$ (d, J = $15.4 \mathrm{~Hz}, \mathrm{H}-8^{\prime}$ and $\left.\mathrm{H}-8^{\prime \prime}\right), \delta$ $6.76 / 6.78\left(d, \mathrm{~J}=3.3 \mathrm{~Hz}, \mathrm{H}-5^{\prime}\right.$ and $\left.\mathrm{H}-5^{\prime \prime}\right), \delta 6.94 / 6.97\left(d d, \mathrm{~J}=2.0\right.$ and 6.4, C-6' and C-6' $\left.{ }^{\prime}\right), \delta$ 7.06/7.07 $\left(d, \mathrm{~J}=2.0 \mathrm{~Hz}, \mathrm{C}-2^{\prime}\right.$ and $\left.\mathrm{C}-2^{\prime \prime}\right), \delta$ 7.62/7.66 $\left(d, \mathrm{~J}=15.9 \mathrm{~Hz}, \mathrm{C}-7^{\prime}\right.$ and $\left.\mathrm{C}-7^{\prime \prime}\right) ;{ }^{13} \mathrm{C}-\mathrm{NMR}\left(\mathrm{CD}_{3} \mathrm{OD}, 100\right.$ $\left.\mathrm{MHz}, \mathrm{CD}_{3} \mathrm{OD}=49,15 \mathrm{ppm}\right): \delta 72.17(\mathrm{C}-3$ and $\mathrm{C}-4), \delta 75.07(\mathrm{C}-2$ and $\mathrm{C}-5), \delta 114.61 / 114.92\left(\mathrm{C}-8^{\prime}\right.$ and $\left.\mathrm{C}-8^{\prime \prime}\right), \delta 115.32\left(\mathrm{C} 2^{\prime}\right.$ and $\left.\mathrm{C} 2^{\prime \prime}\right), \delta 116.63\left(\mathrm{C}-5^{\prime}\right.$ and $\left.\mathrm{C}-5^{\prime \prime}\right), \delta 123.30 / 123.39$ (C-6' and $\left.\mathrm{C}-6^{\prime \prime}\right), \delta$ 127.90/128.02 (C-1' and C-1' '), $\delta 146.98$ (C-3' and C-3' '), $\delta 147.97$ (C-7' and C-7' '), $\delta 149.89$ (C-4' and $\left.\mathrm{C}-4^{\prime \prime}\right), \delta 168.27 / 168.63$ (C-9' and C-9' '), signals for C-1 and C-6 are missing.

\section{Acknowledgements}

The authors thank Dr. Lahl and Mrs Heim, Münster, for recording the NMR spectra. Thanks are also due to Mr Meiners, Münster, for MS measurements, and Mrs Liefländer-Wulf for technical assistance.

\section{References and Notes}

1. Locock, R. A. Boneset Eupatorium. C. P. J. 1990, 123, 229-233.

2. Hall, T. B., Jr. Eupatorium perfoliatum. A plant with a history. Mo. Med. 1974, 71, 527-528.

3. Madaus, G. Abteilung I: Heilpflanzen. In Lehrbuch der biologischen Heilmittel; Georg-ThiemeVerlag: Leipzig, Germany, 1938; Vol. 2. 
4. Moerman, D. E. Medicinal Plants of Native America, Volume One; University of Michigan Publishers: Ann Arbor, Michigan, USA, 1986.

5. Habtemariam, S. Activity-guided isolation and identification of free radical-scavenging components from ethanolic extract of boneset (leaves of Eupatorium perfoliatum). Nat. Prod. Commun. 2008, 3, 1317-1320.

6. Wagner, H.; Iyengar, M. A.; Hoerhammer, L.; Herz, W. Flavonol-3-glucosides in eight Eupatorium species. Phytochemistry 1972, 11, 1504-1505.

7. Herz, W.; Gibaja, S.; Bhat, S. V.; Srinivasan, A. Dihydroflavonols and other flavonoids of Eupatorium species. Phytochemistry 1972, 11, 2859-2863.

8. Herz, W.; Kalyanaraman, P. S.; Ramakrishnan, G.; Blount, J. F. Sesquiterpene lactones of Eupatorium perfoliatum. J. Org. Chem. 1977, 42, 2264-2271.

9. Bohlmann, F.; Mahanta, P. K.; Suwita, A.; Suwita, A.; Natu, A. A.; Zdero, C.; Dorner, W.; Ehlers, D.; Grenz, M. Neue Sesquiterpenlactone und andere Inhaltsstoffe aus Vertretern der Eupatorium-Gruppe. Phytochemistry 1977, 16, 1973-1981.

10. Herz, W. Chemistry of the Eupatoriinae. Biochem. Syst. Ecol. 2001, 29, 1115-1137.

11. Dominguez, X. A.; Quintanilla, J. A. Gonzalez; Rojas, M. P. Chemistry of Mexican Eupatorium genus. III. Sterols and triterpenes from Eupatorium perfoliatum. Phytochemistry 1974, 13, 673674.

12. Hooper, S. N.; Chandler, R. F. Herbal remedies of the Maritime [Canada] Indians: phytosterols and triterpenes of 67 plants. J. Ethnopharmacol. 1984, 10, 181-194.

13. Woerdenbag, H. J.; Bos, R.; Hendriks, H. Eupatorium perfoliatum L. - der "durchwachsene" Wasserhanf. Z. Phytother. 1992, 13, 134-139.

14. Vollmar, A.; Schaefer, W.; Wagner, H. Immunologically active polysaccharides of Eupatorium cannabinum and Eupatorium perfoliatum. Part II. Phytochemistry 1986, 25, 377-381.

15. Wagner, H.; Proksch, A.; Riess-Maurer, I.; Vollmar, A.; Odenthal, S.; Stuppner, H.; Jurcic, K.; Le Turdu, M.; Fang, J. N. Immunostimulating polysaccharides (heteroglycans) of higher plants. Arzneimittelforschung 1985, 35, 1069-1075.

16. Wagner, H.; Proksch, A.; Vollmar, A.; Kreutzkamp, B.; Bauer, J. In vitro phagocytosis stimulation by isolated plant materials measured in the phagocytosis-chemoluminescence (CL) model. Planta Med. 1985, 139-144.

17. Nauert, C.; Bentley, C.; Fiebich, B. L. In-vitro-Untersuchung zur entzündungshemmenden Wirkung von Eupatorium perfoliatum (EP). Z. Phytother. 2006, Supplement 1, 27.

18. Benoit, P. S.; Fong, H. H. S.; Svoboda, G. H.; Farnsworth, N. R. Biological and Phytochemical Evaluation of Plants. XIV. Antiinflammatory Evaluation of 163 Species of Plants. Lloydia 1976, 39, 160-171.

19. Habtemariam, S.; Macpherson, A. M. Cytotoxicity and antibacterial activity of ethanol extract from leaves of a herbal drug, boneset (Eupatorium perfoliatum). Phytother. Res. 2000, 14, 575577.

20. Lira-Salazar, G.; Marines-Montiel, E.; Torres-Monzon, J.; Hernandez-Hernandez, F.; SalasBenito, J. S. Effects of homeopathic medications Eupatorium perfoliatum and Arsenicum album on parasitemia of Plasmodium berghei-infected mice. Homeopathy 2006, 95, 223-228. 
21. Bentley, C.; Grünwald, J. Behandlung von 300 Säuglingen, Kleinkindern und Kindern mit akutem grippalem Infekt: Therapieerfolge einer fixen Wirkstoffkombination (Contramutan). Z. Phytother. 2006, Supplement 1, 28.

22. Elsässer-Beile, U.; Willenbacher, W.; Bartsch, H. H.; Gallati, H.; Schulte, M. J.; von Kleist, S. Cytokine production in leukocyte cultures during therapy with Echinacea extract. J. Clin. Lab. Anal. 1996, 10, 441-445.

23. Gassinger, C. A.; Wunstel, G.; Netter, P. A controlled clinical trial for testing the efficacy of the homeopathic drug Eupatorium perfoliatum D2 in the treatment of common cold (author's transl). Arzneimittelforschung 1981, 31, 732-736.

24. Maas, M.; Hensel, A. Eupatorium perfoliatum L. - Alte Arzneipflanze neu entdeckt. Z. Phytother. 2008, 5, 249-254.

25. Pauli, G. F.; Kuczkowiak, U.; Nahrstedt, A. Solvent effects in the structure dereplication of caffeoyl quinic acids. Magn. Reson. Chem. 1999, 37, 827-836.

26. Kuczkowiak, U. Hydroxyzimtsäurederivate und Flavonoide in offizinellen Crataegus-Arten und einem kommerziellen Extrakt sowie Versuche zur stofflichen Zuordnung der Refraktärzeitverlängernden Aktivität. Dissertation. Westfälische-Wilhelms-Universität Münster, 2000.

27. Takenaka, M.; Yan, X.; Ono, H.; Yoshida, M.; Nagata, T.; Nakanishi, T. Caffeic Acid Derivatives in the Roots of Yacon (Smallanthus sonchifolius). J. Agric. Food Chem. 2003, 51, 793-796.

28. Hänsel, R.; Sticher, O. Pharmakognosie - Phytopharmazie; Springer-Verlag: Heidelberg, Germany, 2004; p. 1214.

29. Clavin, M.; Gorzalczany, S.; Macho, A.; Munoz, E.; Ferraro, G.; Acevedo, C.; Martino, V. Antiinflammatory activity of flavonoids from Eupatorium arnottianum. J. Ethnopharmacol. 2007, 112, 585-589.

30. Pagani, F.; Romussi, G. Constituents of Eupatorium cannabinum var syriacum. Farmaco, Ed. Prat. 1967, 22, 771-785.

31. Lang, G. Phytochemische Untersuchung der Blätter von Eupatorium semialatum Benth., einer in Zentralamerika traditionell verwendeten Arzneipflanze ("Bacché"); Dissertation. Heinrich-HeineUniversität Düsseldorf, 2001.

32. Elliger, C. A.; Lundin, R. E.; Haddon, W. F. Caffeyl esters of glucaric acid in Lycopersicon esculentum leaves. Phytochemistry 1981, 20, 1133-1134.

33. Nagels, L.; Van Dongen, W.; Parmentier, F. Cestric acid, a caffeic acid ester from Cestrum euanthes. Phytochemistry 1982, 21, 743-746.

34. Strack, D.; Engel, U.; Weissenboeck, G.; Grotjahn, L.; Wray, V. Ferulic acid esters of sugar carboxylic acids from primary leaves of rye (Secale cereale). Phytochemistry 1986, 25, 26052608.

35. Risch, B.; Herrmann, K.; Wray, V.; Grotjahn, L. 2'-(E)-O-p-coumaroylgalactaric acid and 2'-(E)O-feruloylgalactaric acid in citrus. Phytochemistry 1987, 26, 509-510.

36. Risch, B.; Herrmann, K.; Wray, V. (E)-O-p-coumaroyl-, (E)-O-feruloyl-derivatives of glucaric acid in citrus. Phytochemistry 1988, 27, 3327-3329.

37. Schwaiger, S.; Cervellati, R.; Seger, C.; Ellmerer, E. P.; About, N.; Renimel, I.; Godenir, C.; Andre, P.; Gafner, F.; Stuppner, H. Leontopodic acid - a novel highly substituted glucaric acid 
derivative from Edelweiss (Leontopodium alpinum Cass.) and its antioxidative and DNA protecting properties. Tetrahedron 2005, 61, 4621-4630.

38. Schwaiger, S.; Seger, C.; Wiesbauer, B.; Schneider, P.; Ellmerer, E. P.; Sturm, S.; Stuppner, H. Development of an HPLC-PAD-MS assay for the identification and quantification of major phenolic edelweiss (Leontopodium alpinum Cass.) constituents. Phytochem. Anal. 2006, 17, 291298.

39. Strack, D.; Gross, W.; Wray, V.; Grotjahn, L. Enzymic synthesis of caffeoylglucaric acid from chlorogenic acid and glucaric acid by a protein preparation from tomato cotyledons. Plant Physiol. 1987, 83, 475-478.

40. Takenaka, M.; Nanayama, K.; Ono, H.; Nakajima, H.; Isobe, S. Changes in the concentration of phenolic compounds during growing, storing, and processing of yacon. Nippon Shokuhin Kagaku Kogaku Kaishi 2006, 53, 603-611.

41. Anonymous. Homöopathisches Arzneibuch 2007: Amtliche Ausgabe; Dt. Apotheker-Verl. [u.a.]: Stuttgart, Germany, 2007.

Sample Availability: Samples of the compounds $\mathbf{C 1}$ to $\mathbf{C 6}$ are available from the authors.

(C) 2009 by the authors; licensee Molecular Diversity Preservation International, Basel, Switzerland. This article is an open-access article distributed under the terms and conditions of the Creative Commons Attribution license (http://creativecommons.org/licenses/by/3.0/). 